\title{
Literature Lost
}


This page intentionally left blank 


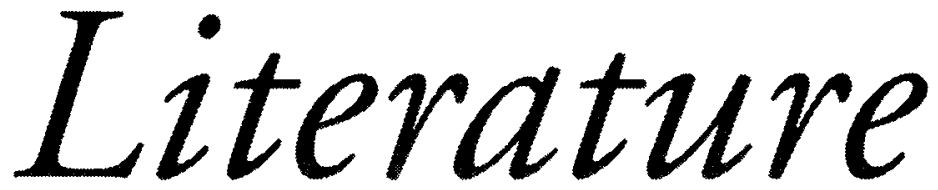

Social Agendas

and the

Corruption of

the Humanities

John M. Ellis 
Published with assistance from the Charles A. Coffin Fund. Copyright (C) 1997 by Yale University. All rights reserved. This book may not be reproduced, in whole or in part, including illustrations, in any form (beyond that copying permitted by Sections 107 and 108 of the U.S. Copyright Law and except by reviewers for the public press), without written permission from the publishers.

Designed by Nancy Ovedoviz and set in Adobe Garamond type by Keystone Typeserting, Inc.

Printed in the United States of America

Library of Congress Cataloging-in-Publication Data Ellis, John M. (John Martin), 1936-

Literature lost : social agendas and the corruption of the humanities / John M. Ellis.

p. $\mathrm{cm}$.

Includes bibliographical references and index.

ISBN : 978-0-300-07579-3 (pbk.)

1. Humanities-Study and teaching (Higher)-United States-

Evaluation. 2.Humanities-Political aspects-United States. 3. Political correctness-United States. 4. Humanities-United States-History.

I. Title.

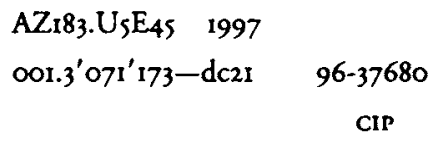

A catalogue record for this book is available from the British Library.

The paper in this book meets the guidelines for permanence and durability of the Commitree on Production Guidelines for Book Longevity of the Council on Library Resources.

10 $\quad \begin{array}{llllll}9 & 8 & 7 & 6 & 5 & 4\end{array}$ 